\section{Antibacterial Power of Sodium Hypochlorite Combined with Surfactants and Acetic Acid}

\author{
Luciano Giardino ${ }^{1}$, Carlos Estrela ${ }^{2}$, Zahed Mohammadi ${ }^{3}$ Flavio Palazzi ${ }^{4}$
}

\author{
'School of Dentistry, Department \\ of Endodontics, Università degli \\ Studi di Torino; and Private \\ Practice, Crotone, Italy \\ ${ }^{2}$ Department of Stomatological \\ Sciences, School of Dentistry, \\ UFG - Federal University of \\ Goiás, Goiânia, GO, Brazil \\ ${ }^{3}$ Iranian Center for Endodontic \\ Research (ICER), Research \\ Institute of Dental Sciences, \\ Shahid Beheshti University of \\ Medical Sciences, Tehran, Iran \\ ${ }^{4}$ Private Practice, Naples, Italy \\ Correspondence: Dr. Luciano Giardino \\ MD,DDS, School of Dentistry, \\ Department of Endodontics, \\ Università degli Studi di Torino; \\ and Private Practice, Crotone, Italy. \\ e-mail:lucianogiardino@libero.it
}

Key Words: sodium hypochlorite, acetic acid, surfactant, Enterococcus faecalis, irrigant.

\section{Introduction}

Bacteria and their byproducts have been long recognized as the primary etiological agents of periapical diseases. The root canal treatment prognosis is influenced by the presence of bacteria in the root canal system (RCS) at the time of filling. Mechanical preparation and disinfection procedures during root canal treatment should completely eradicate all microorganisms in the main root canal and surrounding tooth structure or at least reduce bacterial populations to a level below that necessary to induce or sustain disease. Failure to heal can usually be a result of recontamination of the RCS as well as of residual infection (1).

In fact, microorganisms can penetrate areas that are difficult to clean mechanically and not readily accessible to antimicrobial solutions such as isthmus, ramifications and lateral or accessory canals. Moreover, the dentin wall of an infected root canal can harbor bacteria or bacterial metabolic by-products $(1,2)$. An intense bacterial penetration to about $300 \mu \mathrm{m}$ deep into the dentinal tubules has been reported $(2,3)$; penetration depths $>500$ $\mu \mathrm{m}(4)$ and high prevalence in cases of persistent apical periodontitis (5) have been reported for Enterococcus faecalis. This species is also known to extend even more deeply, penetrating 800-1000 $\mu \mathrm{m}$ into the dentinal tubules after 3 weeks of incubation (4). Additionally endotoxins from Gram-negative bacteria can penetrate dentinal tubules approximately to a depth of 300-500 $\mu \mathrm{m}(6,7)$.

Nonetheless, successful microbial elimination from the infected RCS is still challenging. The ability of $\mathrm{NaOCl}$ to inactivate bacteria is essential, but it must reach areas of difficult access and deeper penetration into dentinal tubules. The greatest penetration of $\mathrm{NaOCl}$ into dentinal tubules has been reported as being $300 \mu \mathrm{m}$ with a $6 \%$ solution for 20 minutes at $45{ }^{\circ} \mathrm{C}(8)$, due to its high surface tension (9). Increasing the concentration of $\mathrm{NaOCl}$ improved the penetration depth of its antibacterial action, but complete eradication of bacteria from the dentinal tubules cannot be achieved, especially beyond the first 300 $\mu \mathrm{m}$ from the pulp-dentin junction (10). Further, irrigants should ideally have adequate antibacterial action against microorganisms and their products without damaging host tissues $(11,12)$. However, $\mathrm{NaOCl}$ does not exert any residual antimicrobial activity (12) so that the recolonization of persistent microorganisms would not be prevented. Thus, infected or contaminated dentin might serve as a potential source of persistent apical periodontitis.

A possible way of improving the bactericidal efficacy of the disinfecting solutions is to incorporate different detergents as surface active agents, enhancing their wetting properties $(13,14)$. High wettability is supposed to enable deeper penetration into the dentinal tubules of the antibacterial solutions. Two commercially available $\mathrm{NaOCl}$-based irrigants modified with surfactants, Hypoclean (Ogna Laboratori Farmaceutici, Muggiò, Italy) and Chlor-Xtra (Vista Dental Products, Racine, WI, USA), showed surface tension values $\left(29.13 \mathrm{~mJ} / \mathrm{m}^{2}\right.$ and $33,14 \mathrm{~mJ} /$ $\mathrm{m}^{2}$, respectively) significantly lower than that of regular $5.25 \% \mathrm{NaOCl}\left(48.90 \mathrm{~mJ} / \mathrm{m}^{2}\right)(9)$. In sequence to this line of 
reasoning, a recent assay showed the superior wettability of Hypoclean and Chlor-Xtra over dentin in comparison to regular $5.25 \% \mathrm{NaOCl}: \mathrm{NaOCl}$ solutions with lowered surface tension spreaded immediately on dentin surface, yielding a zero-degree contact angle (14). Hypoclean demonstrated a more effective antibacterial action against $E$. faecalis than $5.25 \% \mathrm{NaOCl}$ at all experimental periods $(7,14,21$, 28 days) in bovine root dentin and displayed no bacterial growth at the two-first cultures after treatment (12). Low surface tension could improve the antimicrobial efficacy of $\mathrm{NaOCl}$ by increasing its penetration ability into inaccessible areas of the RCS and into dentinal tubules. Nonetheless, for the $6 \%$ solutions a modification of the wetting properties appeared to have no effect on their bactericidal power (15). Thus, the available evidence remains inconclusive regarding the effects of reducing the surface tension of $\mathrm{NaOCl}$ solutions on antimicrobial efficacy.

The bactericidal action of hypochlorite's can also potentially be enhanced by lowering their $\mathrm{pH}$, by its association with acids (16) and by stabilizing them in low pH (17-19) (weak acidification of hypochlorite) (17). Acetic acid resulted a preferable choice because of its own antibacterial activity and safety (18). The $\mathrm{NaOCl}$ solution at s $5.25 \%$ solution was shown to be significantly more effective against $E$. faecalis than weaker $\mathrm{NaOCl}$ solutions within dentinal tubules (20) also in mixed culture. Nonetheless, lower concentrations of $\mathrm{NaOCl}$ tested significantly reduced the microorganisms within dentinal tubules and in the main root canal.

The aim of this study was to assess the in vitro antibacterial power of $1 \% \mathrm{NaOCl}$ in combination with $1 \%$ acetic acid, 5.25\% NaOCl, Hypoclean and ChlorXtra in bovine root dentin infected with $E$. faecalis. The null hypothesis is that these solutions have a similar antibacterial efficacy.

\section{Materials and Methods}

The method of this study was based on the procedure previously described by Haapasalo and Orstavik (4). Sixty extracted bovine permanent maxillary anterior teeth were used. All teeth were kept in $0.5 \% \mathrm{NaOCl}$ solution for up to 7 days. The crown and apical third were removed from each tooth with a rotary diamond saw at $1000 \mathrm{rpm}$ (Isomet Plus precision saw; Buehler, IL, USA) under water cooling. Cementum was removed by using polish paper (Ecomet 3, variable-speed grinder-polisher; Buehler), which resulted in a centre-holed piece of root dentin with a 6-mm outer diameter. The remaining piece of each tooth was then cut into 4-mm thick slices with a diamond saw as above. The root canals of the 4-mm blocks were enlarged (standardized) with an ISO 023 slow speed round bur. In order to prevent dehydration, all teeth and dentin slices were preserved in vials containing tap water during the procedures.

Each dentin block $(n=120)$ was individually treated with $5.25 \% \mathrm{NaOCl}$ and $17 \%$ ethylene diamine tetraacetic acid (EDTA) (pH 7.2) placed in an ultrasonic bath for 10 $\min$, and irrigated under tap water for $1 \mathrm{~h}$ to remove the smear layer. The specimens were then placed in brain heart infusion (BHI) broth (Oxoid, Basingstoke, UK) and autoclaved. To monitor the efficacy of the sterilization they were then kept in an incubator at $37{ }^{\circ} \mathrm{C}$ for $24 \mathrm{~h}$. One bottle of Chlor-Xtra (Vista Dental Products) was purchased shortly before the beginning of the project; the solution was immediately transferred into an amber glass bottle, kept at $4 \mathrm{C}$ (following the recommendations of the manufacturer) and brought to room temperature before use. One percent and $5.25 \% \mathrm{NaOCl}$ solutions were freshly prepared by diluting a stock solution of $15 \% \mathrm{NaOCl}$ (Ogna Laboratori Farmaceutici, Muggiò, Italy) in distilled water.

Hypoclean solution was also freshly prepared by mixing $5.25 \% \mathrm{NaOCl}$ and surfactants. A total of 120 specimens were randomly divided into 6 groups as follows: Group 1: $5.25 \% \mathrm{NaOCl}$ (Ogna) ( $n=25)$; Group 2: Hypoclean $(5.25 \% \mathrm{NaOCl}$ modified with cetrimide and polypropylen glycol) (Ogna) ( $n=25)$; Group 3: Chlor-Xtra $(<6 \% \mathrm{NaOCl}$ modified with Triton X100, proprietary surface modifiers and alkylating agents) (Vista Dental Products) $(n=25)$; Group 4: $1 \% \mathrm{NaOCl}$ (Ogna) with 1\% acetic acid $(n=25)$; Group 5: negative control (sterile dentin tubes) $(n=10)$; Group 6: positive control (infected dentin tubes) $(n=10)$. Mean active chlorine content ( 3 readings) of all solutions was determinate by titration; $\mathrm{pH}$ was determined by using a digital pH meter (Metrohm model $827 \mathrm{pH} \mathrm{LAB}$; Metrohm, Varese, Italy) $5.25 \% \mathrm{NaOCl}-\mathrm{pH} 12.6$ and $\%$ chlorine $=5.2$ $\pm 0.01 ; 1 \% \mathrm{NaOCl}+$ acetic acid $-\mathrm{pH} 3.5$ and \% chlorine $=0.023 \pm 0.06 ;$ Hypoclean $-\mathrm{pH} 12.4$ and $\%$ chlorine 5.1 \pm 0.01 ; Chlor-Xtra - pH 12.7 and \% chlorine $5.42 \pm 0.02$. Isolated 24-h colonies of pure cultures of $E$. faecalis (ATCC 29212) were suspended in $5 \mathrm{~mL}$ of BHI. The bottles containing each specimen in Groups 1, 2, 3, 4 and 6 were opened in a laminar flow chamber. Two milliliters of sterile $\mathrm{BHI}$ were removed with sterile pipettes and replaced with $2 \mathrm{~mL}$ of bacterial inoculum. The bottles were closed and kept at $37^{\circ} \mathrm{C}$ for 28 days, with the replacement of $1 \mathrm{~mL}$ of contaminated BHI for $1 \mathrm{~mL}$ of freshly prepared BHI every 2 days, to avoid medium saturation. After the contamination period, the bacterial growth was verified with a histological technique (Brown and Brenn staining method) (Fig. 1).

Then, each specimen was removed from its bottle under aseptic conditions, and the root canal was irrigated with $5 \mathrm{~mL}$ of sterile saline and dried with sterile paper points. In order to prevent contact of the medicament with the external surface, the outer surface of the specimens was covered with two layers of nail polish. Thereafter, using 
decontaminated sticky wax, specimens were fixed at the bottom of wells of 24-well cell culture plates, which also obliterated the apical surface of the root canal. Finally, the irrigating solutions were delivered into the canal lumen with sterile 3-mL plastic syringes and 27-gauge needles until the dentin tubes were totally filled. Solutions were removed using sterile paper points $10 \mathrm{~min}$ after placement into the lumen. The specimens were then incubated at $37^{\circ} \mathrm{C}$ for 28 days to maintain humidity. At experimental times of $0,7,14$, 21 and 28 days, dentin chips were removed from the root canals with sequential sterile low-speed round burs with increasing diameters of ISO sizes: 025, 027, 029, 031 and 033, respectively (Fig. 2). Each bur removed approximately $0.1 \mathrm{~mm}$ of dentin around the canal. The powder dentin samples obtained with each bur were immediately collected in separate test tubes containing $3 \mathrm{~mL}$ of freshly prepared BHI. Thereafter, $100 \mu \mathrm{L}$ from each test tube was cultured on blood agar. Growing colonies were counted and recorded as colony-forming units (CFU).

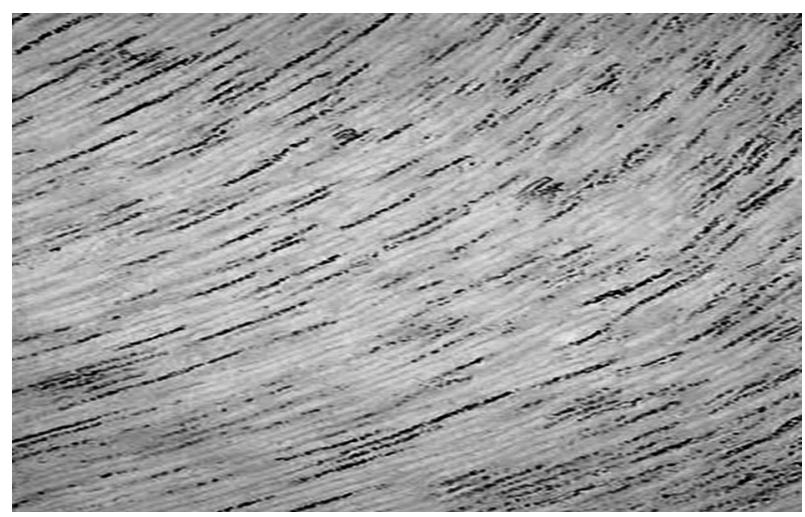

Figure 1. A microscope view (original magnification $\mathrm{X} 400$ ) of stained dentin tube infected in vitro with Enterococcus faecalis for 21 days (Brown and Brenn staining).
Statistical analysis was performed using parametric methods (one-way analysis of variance). Post hoc pair-wise comparisons were performed using Bonferroni's multiple comparisons. The level of significance was set at $p<0.01$. Statistical analysis was carried out using IBM SPSS Statistics 20.0 software (IBM Corp, Armonk, NY, USA).

\section{Results}

The number of CFU obtained from five consecutive dentinal layers at each experimental time is presented in Table 1 The number of CFU in all four experimental groups

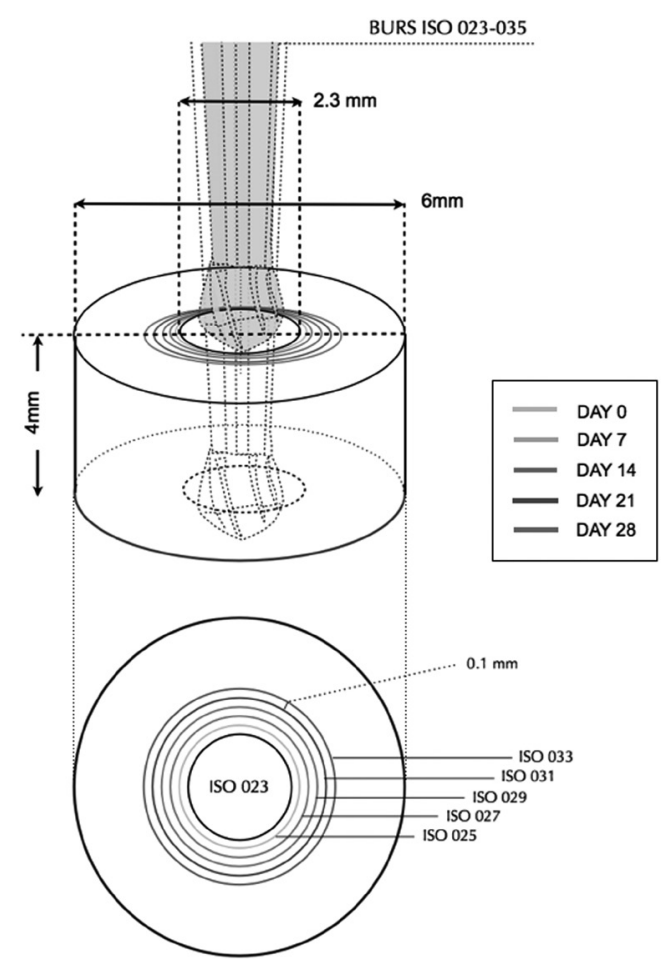

Figure 2. Schematic view of used dentin tubes.

Table 1. Mean numbers and standard deviations of colony forming units (CFU) for the different groups at each experimental time.

\begin{tabular}{lcccc}
\hline \multirow{2}{*}{$\begin{array}{l}\text { Period } \\
\text { (days) }\end{array}$} & $\begin{array}{c}5.25 \% \mathrm{NaOCl} \\
(\mathrm{n}=25)\end{array}$ & $\begin{array}{c}\text { Hypoclean } \\
(\mathrm{n}=25)\end{array}$ & $\begin{array}{c}\text { Chlor-Xtra } \\
(\mathrm{n}=25)\end{array}$ & $\begin{array}{c}\text { Solution } \\
(\mathrm{n}=25)\end{array}$ \\
\cline { 2 - 5 } & $0.43 \pm 0.30^{\mathrm{a}}$ & $0.00 \pm 0.00^{\mathrm{b}}$ & $0.00 \pm 0.00^{\mathrm{b}}$ & $5.52 \pm 0.69^{\mathrm{c}}$ \\
7 & $18.38 \pm 4.29^{\mathrm{d}}$ & $7.41 \pm 1.58^{\mathrm{e}}$ & $10.82 \pm 2.00^{\mathrm{f}}$ & $27.59 \pm 2.72^{\mathrm{g}}$ \\
14 & $35.29 \pm 5.82^{\mathrm{h}}$ & $18.95 \pm 1.12^{\mathrm{i}}$ & $19.00 \pm 3.01^{\mathrm{i}}$ & $43.73 \pm 3.27^{\mathrm{j}}$ \\
21 & $67.47 \pm 7.01^{\mathrm{k}}$ & $31.79 \pm 4.36^{\mathrm{l}}$ & $29.34 \pm 4.16^{1}$ & $65.71 \pm 3.08^{\mathrm{k}}$ \\
28 & $95.08 \pm 3.71^{\mathrm{m}}$ & $48.38 \pm 3.54^{\mathrm{n}}$ & $48.05 \pm 4.16^{\mathrm{n}}$ & $96.62 \pm 3.84^{\mathrm{m}}$ \\
\hline
\end{tabular}

Different superscript letters indicate statistically significant differences among groups $(p<0.01)$. AA: $1 \%$ acetic acid. $\mathrm{n}$ : dentin tubes. 
was minimum after treatment.

The positive control group showed viable bacteria at all experimental times, which indicated the efficiency of the method. The average number of CFU in each specimen of this group was 120 . In contrast, the negative control group showed no viable bacteria at all experimental times. Acidic $\mathrm{NaOCl}$ solution showed the highest number of CFU immediately after treatment $(p<0.001)$ and at days 7 $(p<0.001)$ and $14(p<0.001)$. However, at days 21 and 28 antibacterial effectiveness against $E$. faecalis of $1 \% \mathrm{NaOCl}$ added with $1 \%$ acetic acid versus $5.25 \% \mathrm{NaOCl}$ was not significantly different $(\mathrm{p}<0.01)$. Hypoclean and Chlor-Xtra showed the most effective antibacterial action at all five experimental times $(p<0.001)$. The differences for Hypoclean versus Chlor-Xtra were not statistically significant ( $p>0.01$ ) except for results at day $7(p<0.001)$. For all test solutions the intra-group comparisons among findings at the different experimental times showed significant differences $(p<0.001)$. When surfactants were added to $5.25 \% \mathrm{NaOCl}$ its antibacterial effectiveness increased significantly at all experimental times $(p<0.001)$ with a $38.9 \%$ additional decrease of the CFU recovery at day 28.

\section{Discussion}

The use of teeth or dentin blocks in in vitro and ex vivo studies of root canal disinfection is an effort to bring the experimental conditions much closer to the in vivo reality of the root canal than direct contact tests with planktonic bacteria. The experimental model used in the present investigation was proposed by Haapasalo and Orstavik (4). The time of incubation with the bacteria, the frequency of nutrient exchange and the substrate (surface to attach to) have been taken into account. However, the extent of bacterial growth into the dentin tubules was verified (positive control group).

When $1 \% \mathrm{NaOCl}$ combined with $1 \%$ acetic acid, regular $5.25 \% \mathrm{NaOCl}$ and $5.25 \%$ or $<6 \% \mathrm{NaOCl}$ combined with surfactants have been maintained on infected root surface with E. faecalis during $10 \mathrm{~min}, 40-79 \%$ CFU were recovered at days 28. These results are in accordance with those of a previous in vitro study on bovine root dentin (12).

The chemical characteristics of $\mathrm{NaOCl}$ have made it the most used and studied endodontic irrigant worldwide, but no consensus exists regarding $\mathrm{NaOCl}$ ideal concentration, which ranges from $0.5 \%$ to $6 \%$. High concentration hypochlorites have shown significantly stronger antibacterial efficacy against $E$. faecalis than low concentration hypochlorites into the dentinal tubules (15). In addition, decreased antibacterial properties have been reported for $5.25 \% \mathrm{NaOCl}$ when it is diluted (17). It is well known that increasing the chloride concentration of $\mathrm{NaOCl}$ solutions increases their cytotoxicity (11). The antimicrobial activity of low concentration $\mathrm{NaOCl}$ can potentially be enhanced, with less aggressive action to the periapical tissues, by lowering the $\mathrm{pH}$ of the solution (16), because of it depends on the $\mathrm{HOCl}$ concentration (21). Surely, larger volumes of irrigant and frequent replenishing would be required with weaker $\mathrm{NaOCl}$ solutions to maintain their antibacterial effectiveness. A decrease in $\mathrm{pH}$ increases in the $\mathrm{NaOCl}$ solution the concentration of chlorine available as $\mathrm{HOCl}$ and thus its antimicrobial effectiveness (17). Kuroiwa et al. (18) indicated acetic acid as a preferable acid for safe preparation of acidic hypochlorite solution. Mixtures with other acids consume available chlorine and reduce capacity for bactericidal activity of the solution; acetic acid had no effect on available chlorine. In the present study a combination of $1 \% \mathrm{NaOCl}$ with $1 \%$ acetic acid was tested with the aim of verifying an improved antibacterial activity of low concentration $\mathrm{NaOCl}$ with lowered $\mathrm{pH}$ value. Acidic $\mathrm{NaOCl}$ solution showed the highest number of $\mathrm{CFU}$ immediately after treatment and at days 7 and 14, with a 50,16 \% and 75,91\% recovery of CFU at days 21 and 28 respectively. Kuga et al. (21) evaluated the penetration of $2.5 \% \mathrm{NaOCl}$ combined with 17\% EDTA, 1\% citric acid, and $1 \%$ peracetic acid into dentin tubules. The combination of $\mathrm{NaOCl}$ with acid solutions did not increase its penetration depth into root dentin. According to this finding, the results of the present study showed a recovery of CFU in all evaluated periods. Moreover, differences among the antibacterial efficacy of $1 \% \mathrm{NaOCl}$ added with $1 \%$ acetic acid versus $5.25 \% \mathrm{NaOCl}$ were not significant at days 21 and 28. In the present study, \% chlorine value of $0.023 \pm$ 0.06 and $\mathrm{pH}$ value of 3.5 were determinate by titration for $1 \% \mathrm{NaOCl}$ added with $1 \%$ acetic acid. It is important to point out that the antibacterial effect of $\mathrm{NaOCl}$ is directly related to the amount of $\mathrm{HOCl}$ available, besides the total chlorine present in the solution. Moreover, the addition of acetic acid to $\mathrm{NaOCl}$ in a ratio capable of adjusting the solution $\mathrm{pH}$ would have no effect on the rates of available chlorine (18). In extracted human teeth, hypochlorite solutions with neutral $\mathrm{pH}$ have been shown to be more active against $E$. faecalis than conventional solutions with $\mathrm{pH} 12(16,17)$. Theoretically, with the decrease of $1 \% \mathrm{NaOCl} \mathrm{pH}$ due to the incorporation of acetic acid, the antibacterial power of hypochlorite solutions should increase as a result of the increase of $\mathrm{HOCl}$ concentration. Hypochlorous acid dissociation depends on $\mathrm{pH}$, with the clinical equilibrium between $\mathrm{HOCl}$ and $\mathrm{OCl}^{-}$being maintained as $\mathrm{HOCl}$ is consumed through its germicidal function. Mercade et al. (17) tested in infected ex vivo root canals the antimicrobial efficacy of $4.2 \% \mathrm{NaOCl}$ at two different $\mathrm{pH}$ values by assessing bacterial growth presence or absence following irrigation. A significant increase of the antimicrobial power of $4.2 \% \mathrm{NaOCl}$ solution by weak 
acidification to $\mathrm{pH} 6.5$ was reported with no significant difference between bactericidal activity at $\mathrm{pH} 12$ versus $\mathrm{pH}$ 7.5. At pH 10, basically all chlorine is in the $\mathrm{OCl}^{-}$form and the reverse occurs at a $\mathrm{pH} 4.5$ where all chlorine is in the form of $\mathrm{HOCl}$. At pH 7.5 there is an insufficient increase of $\mathrm{HOCl}$ to compensate for a drop in $\mathrm{pH}$. Further, Fukuzaki (22) reported an increase of $\mathrm{HOCl}$ concentration at $\mathrm{pH} 6$, with $95 \%$ of $\mathrm{HOCl}$ at $\mathrm{pH} 6.5$ and $45 \%$ of $\mathrm{HOCl}$ at $\mathrm{pH} 7.5$. The antimicrobial effectiveness of $\mathrm{NaOCl}$ depends on the $\mathrm{pH}$ and $\mathrm{HOCl}$ concentration $(18,22) . \mathrm{NaOCl}$ solutions show stronger antimicrobial activity when the $\mathrm{pH}$ is close to 5; at a $\mathrm{pH}$ value of 5 , the free chlorine consists of $99 \% \mathrm{HOCl}$ and $1 \% \mathrm{OCl}^{-}$; at a pH value of $4 \mathrm{pH}$ the free chlorine exist as $100 \% \mathrm{HOCl}$; at a $\mathrm{pH}$ value of 3, the free chlorine consists of $95 \% \mathrm{HOCl}$ and $5 \%$ hydrochloric acid. By lowering the $\mathrm{pH}$ to values below 4 , the relative amount of $\mathrm{HOCl}$ diminishes and chlorine gas $\left(\mathrm{Cl}_{2}\right)$ dissolved in water increases at the same rate (23). Chlorine in gas form is unstable because of its volatility (24). In a preliminary evaluation $\%$ chlorine of 1.2 and $\mathrm{pH}$ of 6.4 were recorded for $2.5 \% \mathrm{NaOCl}$ added with $1 \%$ acetic acid; $\%$ chlorine value of 4.6 and $\mathrm{pH}$ value of 7.6 were recorded for $5.25 \% \mathrm{NaOCl}$ added with $1 \%$ acetic acid.

Further areas of study might include what possible combinations of low concentration $\mathrm{NaOCl}$ with acetic acid can provide the ideal $\mathrm{HOCl}$ concentration and the best antibacterial effectiveness. Less production time, less amount of acetic acid and higher bacteria reduction must be taken into account. The main problem of decreasing the $\mathrm{pH}$ of possible combinations of $\mathrm{NaOCl}$ is the instability of the resulting solution. If $\mathrm{NaOCl} \mathrm{pH}$ is lowered below $\mathrm{pH}$ 11 the solution stability grows worse until a very unstable solution is obtained at pH 7 (24). In the present study, the addition of surface active agents increased significantly the antibacterial power of $5.25 \% \mathrm{NaOCl}$ at all experimental times, with residual bacterial activity of $48.38 \pm 3.54$ CFU $(40,31 \%)$ for Hypoclean versus $95.08 \pm 3.71 \mathrm{CFU}(79,23 \%)$ for $5.25 \% \mathrm{NaOCl}$ at day 28. The test solutions with lowered surface tension (Hypoclean and Chlor-Xtra), showed the most effective antibacterial action at all five experimental periods ( $p<0.001$ ). Thus, the null hypothesis tested in the study had to be rejected as differences could be detected in antibacterial efficacy results among all the examined solutions. Nonetheless, surfactants may modify the stability of the chlorine level of $\mathrm{NaOCl}$ solutions $(13,25)$. Chlorine has a strong tendency to acquire electrons in order to achieve greater stability, and this translates into chlorine's oxidizing activity (23). Its oxidizing capacity is retained by $\mathrm{HOCl}$, which may react strongly with surfactants added to hypochlorite solutions causing their degradation and the contemporary acceleration of the kinetics of the chlorine loss. The percentage reduction of chlorine content due to interactions with surface active agents will be greater with low concentration $\mathrm{NaOCl}$ solutions. However, the chemical stability of not freshly prepared hypochlorite solutions with lowered surface tension must be considered. According to he $\%$ chlorine value $(5.42 \pm 0.02)$ recorded for Chlor-Xtra, the differences for Hypoclean versus Chlor-Xtra were not statistically significant $(p>0.01)$ at all experimental periods except for results at day $7(p<0.001)$. The exact $\mathrm{NaOCl}$ and the additional bactericidal effect of cetrimide must be also taken into account to understand these findings. Cetrimide used as single antibacterial agent it was equally effective as $2 \% \mathrm{NaOCl}, 2 \%$ chlorexidine, and iodine potassium iodide against $E$. faecalis into the dentinal tubules (15).

In conclusion, addition of acetic acid to $1 \% \mathrm{NaOCl}$ did not enhance significantly the bactericidal activity of hypochlorite solution. Low concentration acidic chlorinecontaining solutions seem to have lower antimicrobial effect than the currently used $\mathrm{NaOCl}$ concentrations. However, when $\mathrm{CFU}$ recovery for $1 \% \mathrm{NaOCl}$ and $5.25 \% \mathrm{NaOCl}$ were evaluated in comparison, encouraging results were recorded on the way to improve the antibacterial power of low concentration $\mathrm{NaOCl}$. Thus, prospective studies should be conducted with comparisons between these modified irrigating agents, compared in other models of study, the ideal concentration for effective antibacterial power, adverse effects (possibility of interactions, degradation and formation of byproducts) and tissue tolerance. Based on the methodology employed and considering the limitations of this study, all irrigating solutions showed a small number of CFU during 28 days of evaluation.

\section{Resumo}

0 objetivo deste estudo foi verificar o poder antibacteriano do hipoclorito de sódio a $1 \%$ acrescido do ácido acético $1 \%$, do $\mathrm{NaOCl} 5,25 \%$, e de duas soluções irrigadoras modificadas com surfactantes, Hypoclean e ChlorXtra, em tubos de dentina bovina. Um total de 120 tubos de dentina preparados a partir de incisivos bovinos foram infectados durante 28 dias com o Enterococcus faecalis, e aleatoriamente divididos em seis grupos: $\mathrm{NaOCl} 5,25 \%$; Hypoclean; Chlor-Xtra; $\mathrm{NaOCl} 1 \%$ com ácido acético 1\%; tubos de dentina infectados (controle positivo); e tubos de dentina esterilizados (controle negativo). Em períodos de tempo de 0, 7, 14, 21 e 28 dias, raspas de dentina foram coletadas usando brocas esféricas com diâmetros crescentes, e mantidas em tubos de ensaio contendo $3 \mathrm{~mL}$ de infusão cérebro coração (brain heart infusion). A análise dos dados foi feita com testes paramétricos (ANOVA a um fator e teste de comparações múltiplas de Bonferroni, $\alpha=1 \%$ ). Após a cultura, o número de unidades formadoras de colônias (UFC) foi contado. Todas as soluções de hipoclorito de sódio mostraram pequena quantidade de UFC nos periodos por até 28 dias. Chlor Xtra e Hypoclean tiveram menor número de UFC em todos os periodos observados, com maior efetividade antimicrobiana do que 0 $\mathrm{NaOCl} 5,25 \%$ e do que o $\mathrm{NaOCl}$ a $1 \%$ com ácido acético a 1\%.

\section{References}

1. Sundqvist G, Figdor D. Life as an endodontic pathogen - Ecological differences between the untreated and root-filled root canals. Endod Topics 2003;6:3-28.

2. Ando N, Hoshino E. Predominant obligate anaerobes invading the deep layers of root canal dentin. Int Endod J 1990;23:20-27. 
3. Love R. Regional variation in root dentinal tubule infection by Streptococcus gordonii. J Endod 1996;22:290-293.

4. Haapasalo $M, \emptyset$ rstavik D. In vitro infection and disinfection of dentinal tubules. J Dent Res 1987;66:1375-1379.

5. Stuart CH, Schwartz SA, Beeson TJ, Owatz CB. Enterococcus faecalis: its role in root canal treatment failure and current concepts in retreatment. J Endod 2006;32:93-98.

6. Horiba N, Maekawa Y, Matsumoto T, Nakamura H. A study of the distribution of endotoxin in the dentinal wall of infected root canals. J Endod 1990;16:331-334.

7. Nissan R, Segal H, Pashley D, Stevens R, Trowbridge H. Ability of bacterial endotoxin to diffuse through human dentine. J Endod 1995;21:62-64.

8. Zou L, Shen Y, Li W, Haapasalo M. Penetration of sodium hypochlorite into dentin. J Endod 2010;36:793-796.

9. Palazzi F, Morra M, Mohammadi Z, Grandini S, Giardino L. Surface tension comparison of $5.25 \%$ sodium hypochlorite solution with three new sodium hypochlorite-based endodontic irrigants. Int Endod J 2012;45:129-135.

10. Wong DT, Cheung GS. Extension of bactericidal effect of sodium hypochlorite into dentinal tubules. J Endod 2014;40:825-829.

11. Zhang W, Torabinejad M, Li Y. Evaluation of cytotoxicity of MTAD using the MTT-tetrazolium method. J Endod 2003;29:654-657.

12. Mohammadi Z, Mombeinipour A, Giardino L, Shahriari S. Residual antibacterial activity of a new modified sodium hypochloritebased endodontic irrigation solution. Med Oral Patol Oral Cir Bucal 2011;16:e588-e592.

13. Glantz PO, Hansson L. Wetting of dentine by some root canal medicaments. Odontol Revy 1972;23:205-210.

14. Cameron JA. The effect of a fluorocarbon surfactant on the surface tension of the endodontic irrigant, sodium hypochlorite. A preliminary report. Aust Dent J 1986;31:364-368.

15. Giardino L, Morra M, Becce C, Pappen FG, Mohammadi Z, Palazzi F. Comparative wettability of different sodium hypochlorite solutions. Giornalli Ital Endo 2012;26:57-62.

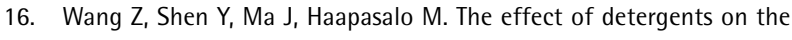
antibacterial activity of disinfecting solutions in dentin. J Endod 2012;38:948-953.

17. Mercade M, Duran-Sindreu F, Kuttler S, Roig M, Durany N. Antimicrobial efficacy of $4.2 \%$ sodium hypochlorite adjusted to $\mathrm{pH} 12,7.5$, and 6.5 in infected human root canals. Oral Surg Oral Med Oral Pathol Oral Radiol Endod 2009;107:295-298.

18. Bremer PJ, Monk I, Butler R. Inactivation of Listeria monocytogenes/ Flavobacterium spp. biofilms using chlorine: impact of substrate, $\mathrm{pH}$, time and concentration. Lett Appl Microbiol 2002;35:321-325.

19. Kuroiwa K, Nakayama H, Kuwahara T, Tamagawa K, Hattori K, Murakami K, et al.. Augmenting effect of acetic acid for acidification on bactericidal activity of hypochlorite solution. Lett Appl Microbiol 2003;36:46-49.

20. Harrison JW, Hand RE. The effect of dilution and organic matter on the antibacterial property of $5.25 \%$ sodium hypochlorite. J Endod 1981;7:128-132.

21. Kuga MC, Gouveia-Jorge E, Tanomaru-Filho M, Guerreiro-Tanomaru JM, Bonetti-Filho I, Faria G. Penetration into dentin of sodium hypochlorite combined with acid solutions. Oral Surg Oral Med Oral Pathol Oral Radiol Endod 2011;112:e155-e159.

22. Fukuzaki S. Mechanisms of actions of sodium hypochlorite in cleaning and disinfection processes. Biocontrol Sci 2006;11:147-157.

23. Hugo WB, Russel AD. Pharmaceutical microbiology. 3rd ed. Oxford: Blackwell Science; 1983. p. 223-224.

24. Lee S-V, Hung Y-C, Chung D, Anderson JL, Erickson MC, Morita K. Effects of storage conditions and $\mathrm{pH}$ on chlorine loss in Electrolyzed Oxidizing (EO) Water. J Agric Food Chem 2002;50:209-12.

25. Adam LC et al. Hypochlorous acid decomposition in the $\mathrm{pH}$ 5-8 region. Inorganic Chem 1992;31:3534-3541. 